\title{
The Influence of the "Controlled Chaos" Technology on the Geopolitical Situation in the Greater Middle East
}

\section{Leyla Suleymanova}

The Academy of Public Administration under the President of the Republic of Azerbaijan International Relation and Foreign Policy 74, Baku, Azerbaijan

Email: nmusayeva@physics.ab.az

How to cite this paper: Suleymanova, L. (2017). The Influence of the "Controlled Chaos" Technology on the Geopolitical Situation in the Greater Middle East. Open Journal of Political Science, 7, 189-196. https://doi.org/10.4236/ojps.2017.72015

Received: February 7, 2017

Accepted: March 25, 2017

Published: March 28, 2017

Copyright $\odot 2017$ by author and Scientific Research Publishing Inc. This work is licensed under the Creative Commons Attribution International License (CC BY 4.0).

http://creativecommons.org/licenses/by/4.0/

\section{(c) (i) Open Access}

\begin{abstract}
The "theory of controlled chaos" popular in the Western political science, stipulates that the existing social systems in the countries of North Africa, should be disintegrated and intermingled. Such a policy conducted by some states can result in voluntary subjugation of the countries of North Africa to their interests. The recent developments in the countries of the Greater Middle East leading to the "new revolutionary wave" clearly prove that these "color" revolutions are not civil domestic conflicts, rather, they have obviously commenced as the outcome of some trends in global politics. The article outlines the techniques of such revolutions which embrace psychological and organizational devices, patters and schemes. The article deals with the political device targeted at shattering the integrity of traditional oriental societies and splitting them into tiny fractions. Such a technique facilitates creation of a major human tool of any "color revolution"- "the political mob" of disoriented citizens capable to trigger the destabilization process in the countries of Maghreb.
\end{abstract}

\section{Keywords}

Greater Middle East, Color Revolutions, Geopolitical, Islamic Terrorism, North Africa, Controlled Chaos

\section{Introduction}

The paper attempts to exert influence of "controlled chaos" technology on the geopolitical situation in the broader Middle East at the present stage. It also reveals the technology of so-called "color revolutions" in some Arab Middle East and North African countries, including the whole arsenal of psychological and 
organizational mass mind control techniques and the creation of the "political crowd", the main ramming tool of any "color revolution" from these misguided people. It is noted that these methods and technologies allow immersing the traditional society into the collapse and political state of "controlled chaos."

The article also notes that the emergence of such a marginal phenomenon on the map of the region as the so-called "Islamic State of Iraq and the Levant" (LIH) has become the decisive factor in the military-political instability in the Middle East and it has a negative impact on the entire system of international security in the region and far beyond its borders. In the process of preparing the article the works of a number of Western and Russian experts in international affairs, as well as materials gleaned from relevant web sites, have been used.

The emergence of new forms and methods of geopolitical rivalry in the Greater Middle East, particularly in the form of the "theory of controlled chaos", the author of which is an American diplomat and political analyst Steven Mann (Mann, 1997), contributes greatly to scientific, theoretical and conceptual significance of the urgent problems of present-day international relations. According to this theory, to ensure voluntary subjugation of the countries of North Africa to the interests of the external state, the clans and communities which unite them, should intermix, i.e. the current traditional social system which still exists in North Africa, has to be disintegrated and intermingled ( $\mathrm{Yu}, 2012)$. This is what is happening in the states which have become the victims of the "new revolutionary wave" (Manoylo, 2011 \& 2012). Apart from it, these "revolutions" are to be considered not in their narrow meaning, as civil domestic conflicts, but rather, in the system of coordinates relative to global politics (Korovin, 2011).

The resort of the West to the technique of "controlled chaos" manifested in the so-called "color" ("pistachio", "dates") revolutions with the aim of "democratization" of the traditional conservative social systems in a number of Arab states of this region has become an idiosyncratic tendency of the geopolitical processes development in the Greater Middle East.

The techniques of these revolutions embrace the whole arsenal of psychological and organizational devices, patters and schemes, nevertheless, shifting the emphasis towards the methods capable of shattering the integrity of traditional oriental societies and splitting them into the tiny fractions, so as to pull some individuals out of the ancestral and tribal clans, disorient them in the political situation with the help of the mass consciousness manipulation techniques and to create a major battering ram tool of any "color revolution"- "the political mob" from such disoriented citizens. The methods and techniques capable of splitting the traditional societies into separate fragments, submerging the society into the state of disintegration and political chaos ruled by its laws, are referred to as techniques of "controlled chaos".

On the whole, the fact that the process of submersion of North Africa and a part of the Middle East into the "controlled chaos" began in 2010s proves that the time to revise the former agreements of a number of Arab states with the world leaders, with the USA first of all, has obviously come. If it is Washington 
that masterminds the "Arab spring", the reformatting of the map of North Afri$\mathrm{ca}$ and the Middle East can pursue two main purposes.

First, the true aims of "color revolutions" in a number of states of the Greater Middle East are undoubtedly rooted much deeper than in the mere change of political regimes. Besides, the area adjacent to Maghreb is the point of merging the interests of world political powers that turned North Africa into a peculiar firing ground and a spring-boat for the forthcoming skirmish for the whole African continent, the fiercest battle after the former colonies got their independence. This battle, according to many analysts, will result in a new territorial and energy power redistribution of the black continent.

There are several important reasons why North Africa has a strategic significance for the world economy, including the geopolitical interests of the United States of America and China, as the largest players of the world market; the main reason being oil. The total oil reserves of the North African countries amount $\sim 70$ billion bbl., which accounts for the $\sim 5 \%$ of world oil reserves.

(https://www.cia.gov/library/Publications/the-world-factbook/rankorder/2244ra nk.html. This index of North Africa is second only to that of the Middle East and Eurasia. Moreover, the new oil fields are annually discovered. The USA is trying to reduce the energy dependence on the Middle East, that's why North Africa has lately become a special object of American political interests (Manoylo, 2011 and 2012).

The North African countries possess about third of the whole Chinese oil imports. Besides, the Chinese economy is strongly oriented towards the African gas supplies. The African gas reserves are considerable. They amount to 14.65 trillion $\mathrm{m}^{3}$ that accounts for $7.9 \%$ of world reserves.

Thus, North Africa and the Middle East currently represent the crossing point of vital interests of two superpowers-the USA and China which have already unleashed the irreconcilable struggle for the access to the energy resources and for the political influence in the region.

The countries of Maghreb for Washington are a key region on the map of the world, that's why the exertion of control of it enables to manage the global transit of carbohydrates and other kinds of strategic raw materials for the largest developing economies, China's first of all. The USA's rate of economic growth lags behind its main rival-China, and it is becoming increasingly dependent on China's fast growing economic and political might. Under these circumstances Washington's policy can manifest itself in its desire to keep control of large carbohydrates reserves at any price, to prevent their import to China and Europe and in this way to hold back their economic growth. The resort to national separatists and extremists movements in order to destabilize the uncontrolled regions, i.e. the "controlled chaos" is one of the methods to reach such a goal. The application of these very techniques is obvious nowadays in a number of countries of the Greater Middle East that have survived or are still suffering from "the dates revolution". This is the USA's first main goal and the major reason of the "revolutionary" events in the region: the new leaders who will take office with 
the help of the "color revolutions" and "controlled chaos" techniques will most probably target at blocking or reducing the energy resources export to China.

Second, Washington's main aim may have something to do with the aggravation of competition between the major geopolitical players in this region, where the overwhelming majority of states were established after the collapse of the colonial empires of European parent states in the second half of the XX century. The colonial borders are most likely give way to the new political set-up of the region in the nearest future. By means of setting forth the conception of new geopolitical unit- "the Greater Middle East", the USA is willing to play a key role in this rearrangement. The chain of "color revolutions" in the countries of North Africa and the Middle East may become the first practical step on the way of such implementation.

The years of 2010-2012 for some Arabic countries of the Middle East and North Africa (Egypt, Syria, Lebanon, Jordan, Yemen, Tunisia, and Libya) became the time of outrageous shocks in the domestic political situation and armed conflicts. These were the events named in mass media and in current political language "the Arab spring". The mass protest rallies and marches in the cities and the protesters' clashes with the police and the militants in certain abovementioned countries led to the situation of the national riot and armed confrontation. As a result, the Presidents of Tunisia-Ben Ali, Egypt-Hosni Mubarak, Yemen-Ali Abdallah Saleh lost their positions. Several governments in other countries had to resign. In the course of the armed coup, directly supported by France, the United Kingdom and other NATO countries, as well as Saudi Arabia and Qatar the head of Libya and one of the leaders of the Arab world Muammar Qaddafi was killed in Libya. As for Bashar Assad, the largescale military-political measures to force him to leave the post, even the attempts of his assassination are being undertaken at present.

Anyway, the lack of unbiased and clear estimation of the events of the "Arab spring" is apparent nowadays. However, one shouldn't claim that they were spontaneous, random and uncontrolled. These events became a result of the dissatisfaction of the population of most Arab countries with their living conditions and the existing orders; this dissatisfaction was triggered from the inside of the countries, as well as from the outside.

It is quite obvious that the formation and development of the events of "the Arab spring" took place under the influence of a number of factors. According to Russian political analyst, Major-General A. Gusher, the following factors facilitated them:

- first, the common dissatisfaction of the population of most Arabic states with the worsening of economic situation and living conditions, followed right after the economic recession in the USA and Europe after 2008;

- second, the upsurge of the wave of protests of urban middle class (petty bourgeoisie, a part of intelligentsia, students, etc.) towards the ruling regimes which didn't take any necessary measures to solve the worsening social and economic problems; 
- third, the large-scale corruption among the top officials, the burgeoning nepotism and clan principle, the separatists moods and the repressive nature of their regimes played a great role in formation of the protests and population activity in most of the Arab countries;

- fourth, undoubtedly, the reaction of the most active and progressive part of the population to the rapid growth of the population informatization process during the last decade that gave the people the opportunity to compare their lives with the life of peoples in other countries and to the people asking themselves why they live worse than others (Gusher, 2012).

- Nevertheless, it was merely a common basis for the events of "the Arab spring" development, a general background and a breeding ground for the processes which excited the whole Arab world. Still, the groups of national and foreign-formed from emigrants-secular political opposition, political Islamic organizations, parties and a part of Islamic clergy, as well as the secret service of the USA and some other NATO countries (the United Kingdom, France, and Turkey) acted as the organizing force of "the Arab spring", its ideologists who supplied the protesters with the program and the action algorithm. But the most important thing is that Saudi Arabia and Qatar are the countries that invested the most efforts, their money and influence, to be more exact, to the events of "the Arab spring". With the support of great sums of money, their rich natural resources, the relations of allies with Washington and huge influence in Islamic world, Saudi Arabia and Qatar decided to get rid of the disobedient Arab leaders, to impose their leadership to the Arab and non-Arab Islamic world, to create the coordinated tools so as to suppress dissention in the Islamic world and in this way to secure themselves from any kind of dangerous innovations, claims and encroachments to their power from the part of their competitors, as well as from the opposition (Gusher, 2012).

Besides, an active interference of international Islamic extremists and terrorist organizations and movements are easily traced in all these events.

It's remarkable that each of these groups of initiators and inspirers of "the Arab spring" and other participants of it were pursuing their own purposes. The secular political opposition (i.e. the politicians who had been barred from taking office in Arab countries or had to resign while being on various political stages, former top officials and clans) were targeting at overthrowing the ruling regimes, seizing power or return to their lost positions.

The Islamic political parties and groups were setting wider priority tasks: not only to take power in their countries, but also to reform the whole life of the Arab society on the basis of the Islamic orders, traditions and the norms of Sharia.

Western countries, the USA and the NATO countries first of all, have been pursuing the aims of stripping of power the Arab national leaders disliked by them and Israel, and whose policy hadn't suited Washington and their allies in Middle East for a long time. First of all it concerned Muammar Qaddafi. The 
Americans had made short work of Saddam Hussein earlier, and referring Bashar Assad, they are currently undertaking steps to strip him of power, even to assassinate him.

- Another priority of Western countries was bringing more manageable, obedient regimes to power in the Middle East countries, which would readily hand over the energy resources and not only the resources of their countries under the complete control of the West and curtail the programs of political, economic and military-technical cooperation with Russia, China and Iran (Gusher, 2012).

The armed conflict in Syria turned to the large-scale civil war involving a number of international Islamic terrorist organizations, some Western bodies, as well as certain interference of Turkey and Iran (Syria Prevented an Invasion Attempt of Militants from Turkey, 2012). Alongside with it, the allies of the oppositional armed units are comprised of the mercenaries from other Arab countries, who were also seen actively supporting all kinds of "color revolutions", the militants from Al-Qaeda including (Bogdanov, 2012). Moreover, as the USA Ambassador to UNO Susan Rice stated on May 30, 2012, the escalation of violence in Syria threatens with the crisis to the whole region (Rice, 2012).

Undoubtedly, the emergence of such a marginalized phenomenon on the map of the Middle East as the so-called "Islamic State of Iraq and the Levant" (ISIL) became the newest factor of military political destabilization in the region.

This Islamic terrorist organization has been operating for the recent years predominantly on the territories of Syria and Iraq. It was established in 2006 in Iraq by means of merge of eleven radical Islamist groups headed by the local unit of "Al-Qaeda" (Islamic State of Iraq and the Levant Online). At present "ISIL" represents "a semi-real quasi-state" with the sharia form of government that partly controls the territory of "Sunni triangle" Gusher (2012).

In 2013 the militants of ISIL entered the war against Bashar Assad regime in Syria supporting the anti-governmental forces, where the group got the reputation of the cruelest militant group. It conducts an active extremists' activity and is responsible for a great number of terrorist acts against American and NATO forces on the territory of Iraq, the Iraqi military, as well as against civilians and civil facilities. The organization aims at creation of the Sunni Islamic state on the territory of Syria, Iraq, and Lebanon. In spite of the fact that this movement imposes the idea of strict observance of Islamic laws, it first of all represents the coalition of Shiite opponents of country's authorities which consists both of Islamists and former Iraqi officers of Saddam Hussein's regime (Frederic, 2014).

The group gained its popularity in summer 2014 when the militants unleashed the full-scale offensive to the northern and western regions of Iraq. Within a month the radicals could manage to take under their control several cities - Mosul (the second largest city in Iraq), Tikrit, and a few days later advanced closely to Baghdad. At the end of June the terrorists announced the foundation of their own quasi-state (the so-called "caliphate") which spread from the town of Aleppo in the north of Syria to Daraa province in the east of Iraq. On August 3 the 
terrorists could manage to take two big oil fields under their control. The head of the militants Abdullah Ibrahim as-Samarrai also known as Abu Bakr al-Baghdadi was declared "the Caliph". After the declaration of the state, not recognized by any country, the group, known earlier as "Islam State of Iraq and the Levanta" refused the geographic connection in its name and got the simple name of "Islamic State" (Islamic State of Iraq and the Levant Online). This terrorist entity, which within a year - from June 2014 to June 2015 - was able to occupy half of the territory of Iraq and a significant part of Syria has created a real threat to the entire system of international security not only in the region but also far beyond its borders.

Thousands of adherents of different creed - the Shiites, the Christians, and the Jesuits have already perished from the hands of these militants, notorious for their extreme cruelty, and thousands of other people had to flee the areas occupied by the extremists; many women and children became captives and are being kept in the terrorists' concentration camps. The Iraqi government addressed the international community for help in their struggle with "the Islamic State". The USA military forces came to assist the Iraqi government; they launched dozens of air strikes and bombarded the Islamists' frontlines (ITAR-TASS News, 2014).

The "Kurdish problem" became urgent again after reemergence of "the Islamic State" on the political arena, as it repeatedly happened in the past. A number of Western countries made the decision to assist the units of Kurdish "Peshmerga" which are fighting with the IS militants on Iraqi territory and on the Syrian-Turkish borders. Such countries as the USA, the UK, France, Germany, and Canada are actively helping the Kurds supplying them with the armament. The final outcome of these events will greatly impact the degree of changes on the geopolitical map of the Greater Middle East.

\section{Conclusion}

Thus, the events of recent years show new qualitative changes in the geopolitical rivalry between world and regional powers in the Greater Middle East. Currently, the aspirations of the West, primarily the United States, are increasing to subordinate the region to its long-term geo-economic and geopolitical goals, which is a clear evidence of direct or indirect, through the use of its regional allies, the military intervention in the political processes that are taking place in a number of countries in the region, particularly in Syria and Iraq. And all this is accompanied by the growth of the Islamic factor, one manifestation of which is the emergence of new forms of Islamic extremism and terrorism, in particular in the face of such a marginal phenomenon as ISIL.

This process is largely facilitated by the fact of internal socio-economic and political instability in some countries of the Greater Middle East as well as the incompleteness of some of the political reforms that have strategic importance for the sustainable development of separate countries and the region as a whole. This triggered a series of so-called "color revolutions" and stirred up the forces of Islamic extremism and terrorism in many countries of the Greater Middle 
East, which caused radical changes in the entire geopolitical situation in the region.

\section{References}

Bogdanov, M. (2012). Aleppo Today.

Frederic, A. (2014). What Is "Islamic State of Iraq and the Levant"? Atlantico, 2014, July 1. http://inosmi.ru/world/20140702/221386643.html

Gusher, A. (2012). The Peculiarities and Tendencies of Geopolitical Tendencies Development in the Near and Middle East.

http://www.centrasia.ru/newsA.php?st=1355173380

Islamic State of Iraq and the Levant Online.

https://en.wikipedia.org/wiki/Islamic_State_of_Iraq_and_the_Levant

ITAR-TASS News (2014). The Aircrafts of US Air Force Launched 15 Air Strikes on the Frontlines of "Islamic State" in Iraq.

http://tass.ru/mezhdunarodnaya-panorama/1386879

Korovin, V. (2011). Tsunami of Color Revolutions in the Middle East. Eurasia, IAP, April 4. http://evrazia.org/print.php?id=1619

Mann, S. R. (1997). The Reaction to Chaos. In D. S. Alberts, \& T. J. Czerwinski (Eds.), Complexity, Global Politics, and National Security (pp. 62-68). National Defense University, Washington DC.

Manoylo, A. V. (2011). Revolutions in Middle East and in North Africa: Political Pragmatism and Controlled Chaos Technologies. World and Politics, 9, 59-69.

Manoylo, A. V. (2012). The Arab Spring Revolutions: Modern Concepts, Models, Techniques of International Conflicts Control. International Relations, 1, 72-87. https://istina.msu.ru/publications/article/1961996/

Rice, S. (2012). The Escalation of Violence in Syria Crisis Threatens Entire Region. http://www.golos-ameriki.ru/a/un-syria/1145567.html

Syria Prevented an Invasion Attempt of Militants from Turkey (2012) http://dokwar.ru/publ/novosti_i_sobytija/sobytija/sirija_predotvratila_popytku_vtorzh enija_boevikov_iz_turcii/10-1-0-43

Yu, B. (2012). Controled Chaos Steven Mann's Concept and His Projection on World Politics. Conceptual War, No. 6, 28 November. http://rossaprimavera.ru/article

Submit or recommend next manuscript to SCIRP and we will provide best service for you:

Accepting pre-submission inquiries through Email, Facebook, LinkedIn, Twitter, etc. A wide selection of journals (inclusive of 9 subjects, more than 200 journals)

Providing 24-hour high-quality service

User-friendly online submission system

Fair and swift peer-review system

Efficient typesetting and proofreading procedure

Display of the result of downloads and visits, as well as the number of cited articles

Maximum dissemination of your research work

Submit your manuscript at: http://papersubmission.scirp.org/

Or contact ojps@scirp.org 